PRACE GEOGRAFICZNE

zeszyt 153, 2018, 69-87

doi: 10.4467/20833113PG.18.004.8479

Instytut Geografii i Gospodarki Przestrzennej UJ

Wydawnictwo Uniwersytetu Jagiellońskiego

\title{
UWARUNKOWANIA GYRKULACYJNE TEMPERATURY POWIETRZA W WARSZAWIE W MIESIĄCACH O SKRAJNYCH WARTOŚCIACH WSKAŹNIKA NAO (1951-2015)
}

\author{
Urszula Kossowska-Cezak, Robert Twardos\%
}

\section{Impact of atmospheric circulation on air temperature in Warsaw during months with extreme values of the NAO index (1951-2015)}

Abstract: In winter, western air masses arriving in Europe, including Poland, change the weather for relatively warmer, while an eastern advection tends to bring freezing temperatures. While the NAO provides a quantitative measure of this western advection, its relationship with air temperature is not always clear-cut. For this reason, this study characterises the circulation and thermal conditions over Poland depending on the sign and the value of the NAO index (NAO+, NAO-).

The study is based on NAO values and winter (December - March) monthly temperature records in Warsaw spanning 65 years (1951-2015), as well as on the calendar of circulation types proposed by Lityński. A detailed analysis was performed looking at the top 10 months with the highest $\mathrm{NAO}+$ and NAO-, as well as the top 10 months with the greatest positive and negative deviations from the long-term average air temperature $(\Delta t)$. This selection was based on a premise that the months should largely coincide. The results, however, show certain deviations from previously established patterns in the influence of the $\mathrm{NAO}+\mathrm{NAO}-$ on air temperature in Poland.

Keywords: Atmospheric circulation, NAO, air temperature, Warsaw 
Zarys treści: Napływ mas powietrznych znad Atlantyku z zachodu w zimie sprowadza nad Europę, w tym i nad Polskę, pogodę względnie ciepłą, podczas gdy adwekcja ze wschodu sprowadza pogodę mroźną. Charakterystyką ilościową nasilenia przenosu zachodniego jest wskaźnik NAO. Związek temperatury powietrza w Europie z tym wskaźnikiem nie zawsze jest jednak jednoznaczny. Dlatego w pracy scharakteryzowano warunki cyrkulacyjne i termiczne nad Polską w zależności od znaku i wartości wskaźnika NAO (dalej NAO+ i NAO). Podstawę opracowania stanowią serie 65-letnie (1951-2015) wartości wskaźnika NAO i średnich miesięcznych (od grudnia do marca) wartości temperatury powietrza z Warszawy oraz kalendarz typów cyrkulacji według Lityńskiego. Do analizy wybrano po 10 miesięcy z 65-lecia z największą wartością NAO+ i NAO- oraz po 10 miesięcy o największych dodatnich i ujemnych odchyleniach temperatury od średniej wieloletniej $(\Delta t)$, wychodząc z założenia, że w dużym stopniu powinny to być te same miesiące. Analiza wykazała, że zachodzą jednak odstępstwa od znanych dotychczas prawidłowości wpływu dodatniej lub ujemnej fazy NAO na warunki termiczne w Polsce.

Stowa kluczowe: Cyrkulacja atmosferyczna, NAO, temperatura powietrza, Warszawa

\section{Wprowadzenie}

Badanie wpływu cyrkulacji atmosferycznej na warunki pogodowe - jak słusznie podkreślił Kaszewski (1992) - należy do podstawowych, a zarazem najbardziej złożonych w meteorologii i klimatologii synoptycznej. Dotyczy to zwłaszcza strefy umiarkowanej, w której występuje duża zmienność cyrkulacji, a tym samym warunków pogodowych. W tej strefie dochodzi bowiem do powstawania, ewolucji i przemieszczania się z zachodu na wschód rodzin dynamicznych niżów rozdzielonych klinami wysokiego ciśnienia. Jest to wynikiem układu globalnej cyrkulacji atmosferycznej, która w tej strefie dokonuje się głównie w obrębie komórki cyrkulacyjnej Ferrela, czyli między wyżami podzwrotnikowymi a niżami szerokości umiarkowanych. $\mathrm{Na}$ północnym Atlantyku tymi ośrodkami aktywności atmosferycznej są Niż Islandzki i Wyż Azorski. Wartości ciśnienia atmosferycznego są między nimi ujemnie skorelowane (Marsz 2002), co oznacza, że w okresach spadku ciśnienia w Niżu Islandzkim rośnie ciśnienie w Wyżu Azorskim i odwrotnie. Powiązania obu tych ośrodków barycznych ze sobą - jak wyjaśnia Marsz (2002) - nie są jednak stabilne. Może się zdarzyć, że silny albo słaby może być tylko jeden z tych ośrodków. O istniejących związkach między Niżem Islandzkim i Wyżem Azorskim wiadomo już od ponad 100 lat (Merecki 1914), a które to zjawisko w latach 20. XX w. nazwano Oscylacją Północnoatlantycką - NAO (Wibig 2000; Nowosad 2005). Termin „oscylacja” wskazuje na ciągłe wahania gradientu ciśnienia między tymi ośrodkami, zarówno w przebiegu rocznym, jak i wieloletnim. Miarą wielkości tej oscylacji jest wielkość nazwana wskaźnikiem (indeksem) NAO. Ponieważ służy on do opisu tylko jednej cechy pola ciśnienia, jest zaliczany do grupy wskaźników cyrkulacji (Wibig 2001), które obok 
typologii cyrkulacji są wykorzystywane do analizy przyczyn zmienności pogody i klimatu. Nowoczesne wskaźniki NAO, o jednoznacznym sensie fizycznym, zaczęto opracowywać w latach 80. XX w. (Wibig 2000, 2001; Marsz 2002). Chociaż jest ich kilka wersji, to jednak zasada ich opracowywania jest niezmienna, a mianowicie jest to różnica standaryzowanych wartości ciśnienia między Wyżem Azorskim a Niżem Islandzkim, określona na podstawie wartości ciśnienia pochodzących z różnych miejsc (Rogers 1984; Hurrell 1995; Jones i in. 1997; Marsz 2002).

Pomimo że zjawisko Oscylacji Północnoatlantyckiej jest znane od dawna, to jednak potocznie najczęściej jest utożsamiane ze wskaźnikiem tej oscylacji (wskaźnik NAO). Jest on jednak tylko charakterystyką liczbową tej oscylacji. O wskaźniku tym jest mowa m.in. w Stowniku meteorologicznym pod red. T. Niedźwiedzia (2003), a w amerykańskim Glossary of Meteorology (2000) jest utożsamiana z tym wskaźnikiem. W Międzynarodowym Słowniku Meteorologicznym (International... 1992) nie ma żadnej wzmianki o oscylacji ani też o wskaźniku tej oscylacji. W polskiej literaturze klimatologicznej Oscylacja Północnoatlantycka jest różnie definiowana, ale wydaje się, że nie do końca wyczerpująco. Na przykład, Marsz (2002) opisuje ją jako „wielkoskalowe zjawisko klimatyczne działające w rejonie Północnego Atlantyku, którego skutki obejmują rozległe przestrzenie półkuli północnej...”, a Wibig (2000) jako „...zjawisko skorelowania wysokiego ciśnienia w Wyżu Azorskim i niskiego w Niżu Islandzkim i zmian gradientu między tymi ośrodkami...” Zdaniem autorów Oscylację Północnoatlantycką można zdefiniować jako zjawisko ciągłej zmienności wielkości i kierunku gradientu ciśnienia atmosferycznego między Wyżem Azorskim i Niżem Islandzkim.

\section{Cel i zakres badań}

Uzyskane charakterystyki ilościowe cyrkulacji zachodniej (lub jej braku) nad wschodnią częścią Atlantyku w szerokości geograficznej Europy w postaci wskaźnika NAO stworzyły możliwość zbadania związku temperatury powietrza w Polsce w poszczególnych miesiącach zimowych z występującymi wówczas znakiem i wartością tego wskaźnika. Ponieważ jednak temperatura w Polsce jest bezpośrednio kształtowana przez cyrkulację nad jej obszarem, badanie związku temperatury powietrza z NAO powinno objąć etap pośredni, to znaczy analizę cyrkulacji atmosferycznej nad Polską. Jest to w pełni uzasadnione, gdyż jak stwierdził Kaszewski (1992), na mniejszych obszarach mogą występować odmienne niż w makroskali procesy mezocyrkulacyjne, uwarunkowane regionalnymi czynnikami geograficznymi. Dobitnie to pokazał Niedźwiedź (2002), określając statystyczny związek wskaźnika cyrkulacji strefowej nad Polską ze wskaźnikiem NAO. Uzyskane przez tego autora współczynniki korelacji były istotne tylko od grudnia do kwietnia, z największą zależnością w lutym $(r=0,66)$. Opracowanie to sprowadza się zatem do uzyskania odpowiedzi na 
pytanie, jak określona faza NAO i jej natężenie wpływa na temperaturę powietrza w odległości prawie 2 tysięcy kilometrów od wybrzeży Atlantyku. Na tej przestrzeni morskie masy powietrzne nie tylko ulegają znacznej transformacji, ale też tworzące się nad Europą układy baryczne mogą powodować zmianę pierwotnego kierunku przemieszczania się tych mas. W środkowej Europie związek temperatury powietrza w okresie zimowym z fazą NAO dodatnią lub ujemną może, ale nie musi być zatem silny ani nawet jednoznaczny, aczkolwiek liczne opracowania (a także potoczna obserwacja) wskazują na istnienie takiego związku.

\section{Dane i metody badań}

Podstawę opracowania stanowią serie 65-letnie (1951-2015) wartości wskaźnika NAO obliczanego jako różnica ciśnienia atmosferycznego między Gibraltarem i południowo-zachodnią Islandią (Jones i in. 1997). Wartości te pozyskano ze strony internetowej Climate Research Unit (http://www.cru.uea.ac.uk/cru/data/nao.htm). Drugi zestaw danych stanowią średnie miesięczne wartości temperatury powietrza z Warszawy (Okęcie) oraz kalendarz typów cyrkulacji według Lityńskiego (1969), opracowany przez Pianko-Kluczyńską (2007). Kalendarz ten obejmuje 27 typów cyrkulacji, w tym po 9 typów cyklonalnych, „0” (typów pośrednich) i antycyklonalnych z 8 kierunków i 9. typ bezadwekcyjny. W pierwszym etapie opracowania objęto 5 najchłodniejszych miesięcy roku. Po uzyskaniu wstępnych wyników w dalszej części opracowania zrezygnowano z listopada, ograniczając właściwe opracowanie do 4 miesięcy, od grudnia do marca. Do szczegółowych badań związku temperatury i cyrkulacji atmosferycznej wybrano miesiące o największej dodatniej i ujemnej wartości wskaźnika NAO oraz o największym odchyleniu średniej temperatury, dodatnim i ujemnym, od średniej wieloletniej. Następnie obliczono częstość typów cyrkulacji w tych miesiącach.

\section{Faza i nasilenie NAO a temperatura średnia w Warszawie}

Na podstawie dotychczasowych badań wiemy, że Oscylacja Północnoatlantycka najsilniej oddziałuje na temperaturę w zimie, a więc w porze, w której ciśnienie atmosferyczne w Niżu Islandzkim jest najniższe i wyraźnie dominuje zachodnie przemieszczanie mas powietrznych. Jest to wynik największych w roku kontrastów termicznych między masami powietrznymi w pozazwrotnikowych obszarach półkuli północnej. Dlatego też istotne statystycznie współczynniki korelacji średniej temperatury powietrza ze wskaźnikiem NAO uzyskuje się tylko w porze zimowej (np. Hurrell, van Loon 1997; Ustrnul, Czekierda 2007; Kirschenstein, Baranowski 2009; Marsz 2013; Świątek 2014). Jak wynika z badań Wibig (2001), w styczniu nad 
całym kontynentem, oprócz północnej Skandynawii i południowego krańca Półwyspu Iberyjskiego, współczynniki te są dodatnie, a w części środkowej wyniosły około 0,7, co oznacza, że $50 \%$ zmienności temperatury jest skutkiem zmian NAO.

Zależność temperatury w Warszawie w miesiącach zimowych w rozpatrywanym 65-leciu od wartości wskaźnika pokazano na rycinie 1. Widać dobitnie, że większość wartości obu charakterystyk wyraźnie odbiega od linii zależności i 95\% przedziału ufności.

Badanie warunków cyrkulacyjnych i termicznych nad Polską w zależności od znaku i wartości wskaźnika NAO (dalej NAO+ i NAO-) oparto jednak nie na pełnej 65-letniej serii średnich wartości z 5 miesięcy (listopad-marzec, razem 325 miesięcy), lecz na wartościach z wybranych miesięcy. Do analizy przyjęto przede wszystkim po 10 miesięcy z 65-lecia z największą wartością NAO+ $(5 \times 10=50)$ i NAO- (również 50). Ponieważ można oczekiwać, że wartościom dodatnim wskaźnika NAO (NAO+) odpowiada w Polsce temperatura powyżej średniej wieloletniej $(\Delta t+)$, a wartościom ujemnym (NAO-) - poniżej średniej wieloletniej ( $\Delta \mathrm{t}-$ ), wzięto też pod uwagę po 10 miesięcy z 65-lecia od listopada do marca o największych dodatnich i ujemnych $\Delta \mathrm{t}$ (razem 103 miesiące, ponieważ w 2 miesiącach dziesiąta wartość wystąpiła więcej niż w jednym roku). Podstawowe charakterystyki statystyczne uwzględnionych wartości wskaźnika NAO i średnich miesięcznych wartości temperatury w Warszawie zestawiono w tabeli 1.

Tab. 1. Podstawowe charakterystyki statystyczne wartości wskaźnika NAO w zależności od jego znaku i wartości (NAO+ i NAO-, wartości niemianowane) i temperatury powietrza (średniej wieloletniej i odchylenia od tej średniej - $\Delta \mathrm{t},{ }^{\circ} \mathrm{C}$ ) w latach 1951-2015

Table 1. Main statistical patterns linking NAO+ and NAO-, and air temperatures (long term average and deviations from it $\Delta \mathrm{t},{ }^{\circ} \mathrm{C}$ ) in $1951-2015$

\begin{tabular}{|l|c|c|c|c|c|}
\hline \multirow{2}{*}{$\begin{array}{c}\text { Charakterystyki statystyczne } \\
\text { Statistical characteristics }\end{array}$} & \multicolumn{5}{c|}{ Miesiące / Months } \\
\cline { 2 - 6 } & XI & XII & I & II & III \\
\hline Wartość średnia NA0 / mean value of NA0 & $-0,05$ & 0,17 & 0,45 & 0,50 & 0,31 \\
\hline Liczba miesięcy z NA0+ / Number of months & 30 & 34 & 42 & 39 & 41 \\
\hline Największa NA0+ / highest NA0+ & 4,52 & 4,22 & 4,82 & 5,26 & 3,68 \\
\hline 10. wartość NA0+ / 10 ${ }^{\text {th }}$ highest value of NA0+ & 1,68 & 2,54 & 2,43 & 2,46 & 2,03 \\
\hline Największa NA0- / highest NA0- & $-3,34$ & $-4,70$ & $-4,09$ & $-4,02$ & $-3,78$ \\
\hline 10. wartość NA0- / 10 th highest value of NA0- & $-2,06$ & $-2,08$ & $-1,64$ & $-1,53$ & $-1,37$ \\
\hline Średnia temperatura / mean temperature & 3,2 & $-0,7$ & $-2,6$ & $-1,8$ & 2,0 \\
\hline Największa $\Delta \mathrm{t}+/$ highest $\Delta \mathrm{t}+$ & 3,1 & 5,4 & 6,5 & 6,5 & 5,2 \\
\hline 10. wartość $\Delta \mathrm{t}+/ 10^{\text {th }}$ highest values of $\Delta \mathrm{t}-$ & 2,2 & 2,7 & 3,0 & 3,7 & 2,6 \\
\hline Największa $\Delta \mathrm{t}-$ / highest $\Delta \mathrm{t}-$ & $-5,9$ & $-7,8$ & $-9,8$ & $-10,4$ & $-5,0$ \\
\hline 10. wartość $\Delta \mathrm{t}-/ 10^{\text {th }}$ highest values of $\Delta \mathrm{t}-$ & $-1,7$ & $-3,4$ & $-3,6$ & $-3,8$ & $-3,4$ \\
\hline
\end{tabular}




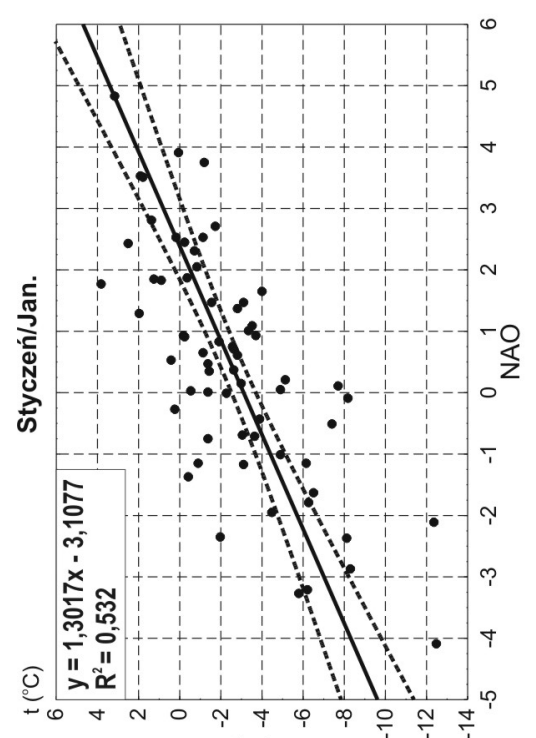

(כ) $)$

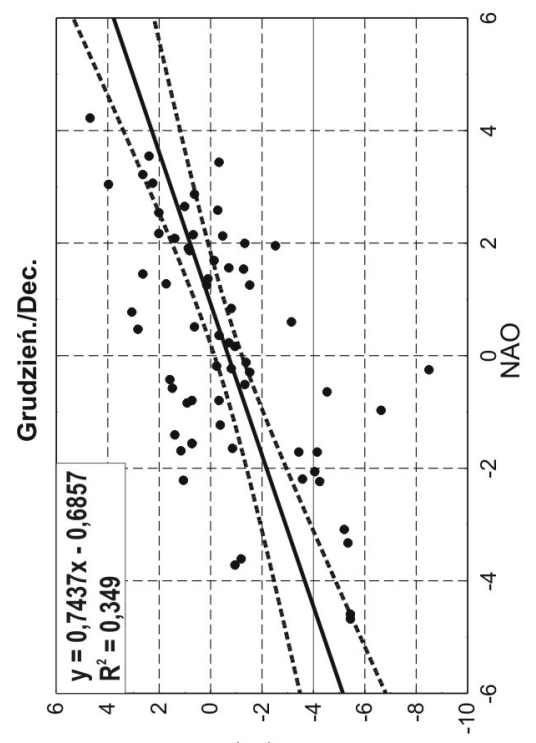

(כ) 1

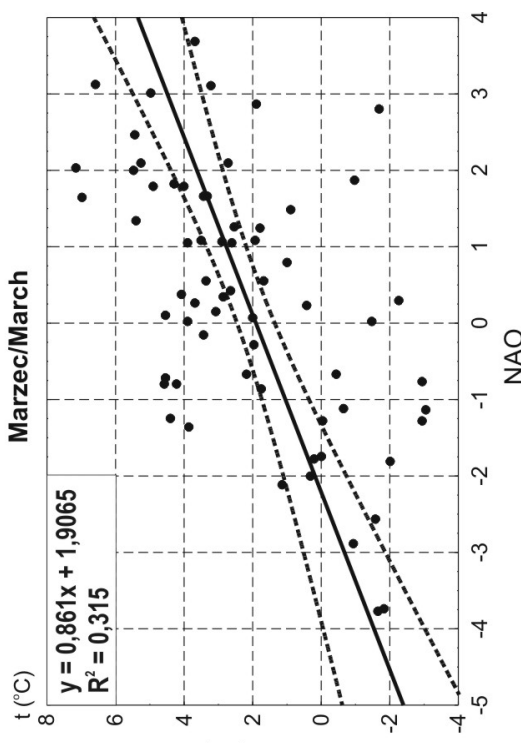

(כ०) 7

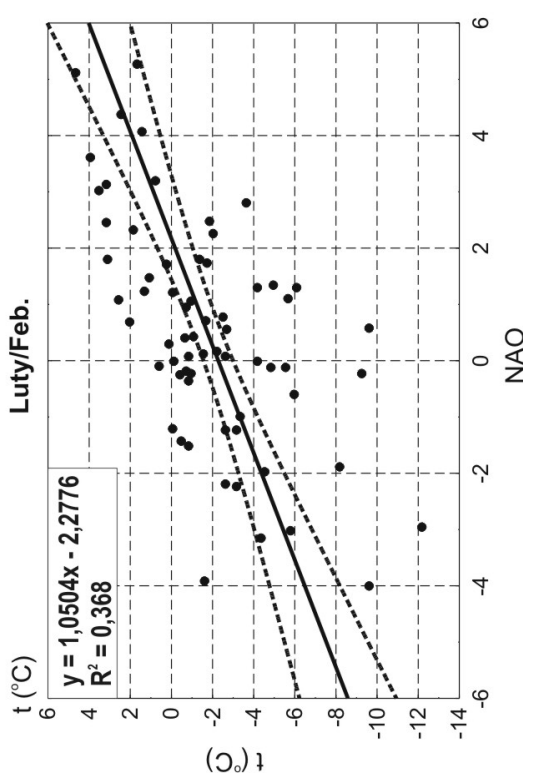

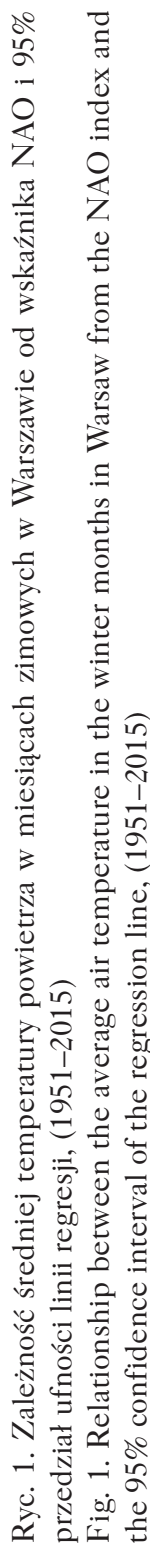


Gdyby zachodził ścisły związek między miesięcznymi wartościami NAO i $\Delta t$, to miesiące wyłonione niezależnie według każdego kryterium (NAO albo $\Delta \mathrm{t}$ ) byłyby te same, a przy braku takiego związku zupełnie różne. W rzeczywistości okazało się, że spośród tak wybranych miesięcy tylko połowa tych z największym NAO+ jednocześnie należała do grupy z największą $\Delta \mathrm{t}+$; podobnie było w przypadku miesięcy z dużym NAO- i $\Delta \mathrm{t}-$. $\mathrm{W}$ miesiącach zakwalifikowanych do dalszej analizy ze względu na duże NAO+/-albo $\Delta \mathrm{t}+$ /- najczęściej znaki obu wartości były zgodne, ale stwierdzono również miesiące, w których znaki ich były przeciwne: $\mathrm{NAO}+/ \Delta \mathrm{t}-\mathrm{i} \mathrm{NAO}-/ \Delta \mathrm{t}+$. Najmniej miesięcy wyłonionych zgodnie według obydwu kryteriów (duże NAO i $\Delta \mathrm{t}$ ) i najwięcej z przeciwnymi znakami NAO i $\Delta$ t było w listopadzie. Ten wynik wraz z faktem, że średnia wieloletnia wartość NAO w tym miesiącu jest bliska zeru i w ciągu 65 lat było więcej miesięcy z NAO- niż NAO+ (tab. 1), zdecydowały o wyłączeniu tego miesiąca $\mathrm{z}$ dalszego opracowania. Wynik ten jest jednak podstawą do wniosku, że w listopadzie wpływ fazy i nasilenia NAO na temperaturę powietrza w środkowej Europie jeszcze się nie zaznacza, prawdopodobnie z powodu zbyt małego zróżnicowania termicznego mas powietrznych pochodzenia morskiego i kontynentalnego.

W tym miejscu należy zwrócić uwagę, że zestawione średnie miesięczne wartości wskaźnika (indeksu) NAO i wielkości odchylenia temperatury średniej miesięcznej od odpowiedniej średniej wieloletniej, mimo formalnego podobieństwa (+ albo -), są wielkościami zupełnie różnego rodzaju. Indeks NAO informuje o układzie ośrodków barycznych nad północnym Atlantykiem; przeciętnie (i najczęściej)
Tab. 2. Liczba miesięcy z dużym NAO +/- i/albo dużą $\Delta \mathrm{t}+/-(1951-2015)$

Table 2. Number of months with high $\mathrm{NAO}+/-$ and/or high $\Delta \mathrm{t}+/-(1951-2015)$

\begin{tabular}{|c|c|c|c|c|c|c|}
\hline & & XII & I & II & III & XII-III \\
\hline \multirow{3}{*}{$N A 0+$} & $\Delta \mathrm{t}+$ & 6 & 5 & 5 & 5 & 21 \\
\cline { 2 - 7 } & $(\Delta \mathrm{t}+)$ & 4 & 5 & 4 & 3 & 16 \\
\cline { 2 - 7 } & $(\Delta \mathrm{t}-)$ & - & - & 1 & 2 & 3 \\
\hline \multirow{4}{*}{$\Delta \mathrm{t}+$} & $\mathrm{NAO}+$ & 6 & 5 & 5 & 5 & 21 \\
\cline { 2 - 7 } & $(\mathrm{NAO}+)$ & 4 & 5 & 5 & 5 & 19 \\
\cline { 2 - 7 } & $(\mathrm{NAO}-)$ & - & - & - & 2 & 2 \\
\hline \multirow{3}{*}{$\mathrm{NAO}-$} & $\Delta \mathrm{t}-$ & 7 & 7 & 4 & 4 & 22 \\
\cline { 2 - 7 } & $(\Delta \mathrm{t}-)$ & 2 & 2 & 4 & 5 & 13 \\
\cline { 2 - 7 } & $(\Delta \mathrm{t}+)$ & 1 & 1 & 2 & 1 & 5 \\
\hline \multirow{3}{*}{$\Delta \mathrm{t}-$} & $\mathrm{NAO}-$ & 7 & 7 & 4 & 4 & 22 \\
\cline { 2 - 7 } & $(\mathrm{NAO}-)$ & 3 & 2 & 3 & 3 & 11 \\
\cline { 2 - 7 } & $(\mathrm{NAO}+)$ & - & 1 & 3 & 3 & 7 \\
\hline
\end{tabular}

Objaśnienia: $\mathrm{NAO}+/--$ miesiące o wskaźniku NAO dodatnim/ujemnym, $\Delta \mathrm{t}+$ /-- miesiące o odchyleniu temperatury od średniej wieloletniej dodatnim/ujemnym; symbol bez nawiasu - wartość „duża”, tzn. jedna z 10 największych w 65-leciu, symbol w nawiasie - wartość mniejsza od dziesiątej największej w 65-leciu.

Explanations: $\mathrm{NAO}+/--$ months with a positive/negative NAO index, $\Delta \mathrm{t}+/--$ months with a positive/negative deviation of temperatures from the multiannual average; symbol without parentheses - "high" value, i.e. one of the 10 highest values in the 65-year period, symbol in parentheses - value lower than the tenth highest in the 65 -year period. 
jest to Wyż Azorski i Niż Islandzki, co oznacza utrzymanie się gradientu ciśnienia skierowanego z południa na północ, co wyraża się dodatnią wartością wskaźnika NAO (NAO+). Zmiany położenia tych ośrodków i wartości ciśnienia w ich zasięgu sprawiają, że wskaźnik NAO stale zmienia wartość, a okresowo znak. Stanowi on zatem obiektywną informację o pewnym stanie rozkładu ciśnienia atmosferycznego. Odchylenie temperatury w danym miesiącu od średniej wieloletniej jest natomiast charakterystyką względną, gdzie w każdej serii wartości miesięcznych w wieloleciu suma odchyleń wynosi zero. Jak wynika z zestawienia w tabeli 2., w miesiącach od grudnia do marca o dużym NAO+ albo o dużej $\Delta \mathrm{t}+$ znak drugiej charakterystyki był przeciwny ( $\Delta \mathrm{t}-$, NAO-) zaledwie w 5 miesiącach, natomiast w miesiącach o dużym NAO-albo o dużej $\Delta$ t- przypadków takich było ponad 2 razy więcej-12. Potwierdza się zatem, zgodnie z oczekiwaniem, większa zgodność znaków NAO i temperatury $\Delta \mathrm{t}$ w przypadku ich wartości dodatnich niż ujemnych. Należy to wiązać z różną liczbą typów pola ciśnienia atmosferycznego nad Atlantykiem Północnym i Europą podczas dodatniej i ujemnej fazy NAO. Według Styszyńskiej (2002) dodatniej fazie NAO odpowiada jeden lub dwa typy pola ciśnienia, a podczas ujemnej fazy liczba możliwych typów rozkładu tego pola może być bardzo różna.

\section{Cyrkulacja atmosferyczna nad Polską w wybranych miesiącach o dużej wartości średniej miesięcznej NAO i/albo $\Delta t$}

We wszystkich miesiącach, w których wystąpiła duża wartość NAO i/albo $\Delta \mathrm{t}$ (tzn. jedna z 10 największych dodatnich i ujemnych) (tab. 1), obliczono częstość typów cyrkulacji nad Polską według Lityńskiego (1969), opracowanych przez Pianko-Kluczyńską (2007). Następnie obliczono średnią liczbę dni z cyrkulacją z poszczególnych kierunków oraz z cyrkulacją cyklonalną, zerową i antycyklonalną w poszczególnych kategoriach miesięcy wyróżnionych ze względu na znak i wielkość NAO i $\Delta$ t. Zestawiając miesiące wybrane ze względu na dużą wartość NAO i/albo $\Delta$ t, jako pierwotną charakterystykę przyjęto wskaźnik NAO (tab. 3). Przeciętną liczbę dni z cyrkulacją z każdego kierunku i o różnym charakterze podano w wartościach całkowitych w miesiącu 31-dniowym.

\section{Miesiące o dodatniej wartości wskaźnika NAO}

We wszystkich miesiącach od grudnia do marca, w których wystąpiła dodatnia faza NAO i w Warszawie temperatura średnia wyższa od średniej wieloletniej, zaznaczyła się nad Polską wyraźna przewaga dni z cyrkulacją z sektora zachodniego i mała liczba dni z cyrkulacją z sektora wschodniego. 
Tab. 3. Średnia liczba dni w miesiącu z cyrkulacją z poszczególnych kierunków i o różnym charakterze (według Lityńskiego 1969; Pianko-Kluczyńskiej 2007); boldem oznaczono wartości największe, C - typy cyklonalne, 0 - typy „0” (typy pośrednie), A - typy antycyklonalne Table 3. Average number of days in a month with circulation from the individual directions and of different nature (according to Lityński 1969); the highest values are marked with bold type, $\mathrm{C}$ - cyclonic types; 0 - types "0" (transitional types); A - anticyclonic types

\begin{tabular}{|c|c|c|c|c|c|c|c|c|c|c|c|c|c|}
\hline $\begin{array}{c}\text { Kategoria mies. } \\
\text { Month category }\end{array}$ & $\begin{array}{c}\text { Liczba miesięcy } \\
\text { Number of months }\end{array}$ & N & NE & E & SE & S & SW & W & NW & 0 & C & 0 & A \\
\hline $\mathrm{NAO}+/ \Delta t+$ & 21 & 2 & - & 1 & 1 & 2 & $\mathbf{8}$ & $\mathbf{7}$ & $\mathbf{9}$ & 1 & 10 & 8 & 13 \\
\hline $\mathrm{NAO}+/(\Delta \mathrm{t}+)$ & 16 & 4 & 1 & 1 & 1 & 3 & $\mathbf{6}$ & $\mathbf{6}$ & $\mathbf{7}$ & 2 & 9 & 8 & 14 \\
\hline$(\mathrm{NAO}+) / \Delta \mathrm{t}+$ & 19 & 3 & 1 & 2 & 2 & 4 & $\mathbf{7}$ & $\mathbf{4}$ & $\mathbf{6}$ & 2 & 13 & 8 & 10 \\
\hline$(\mathrm{NAO}+) / \Delta \mathrm{t}-$ & 7 & 3 & 3 & $\mathbf{7}$ & $\mathbf{6}$ & 3 & 2 & 2 & 3 & 2 & 9 & 7 & 15 \\
\hline $\mathrm{NAO}-/ \Delta \mathrm{t}-$ & 22 & 3 & $\mathbf{6}$ & $\mathbf{7}$ & $\mathbf{6}$ & 3 & 1 & 1 & 1 & 3 & 10 & 8 & 13 \\
\hline $\mathrm{NAO}-/(\Delta \mathrm{t}-)$ & 13 & 3 & 3 & $\mathbf{5}$ & $\mathbf{7}$ & 4 & 2 & 2 & 2 & 3 & 13 & 8 & 8 \\
\hline$(\mathrm{NAO}-) / \Delta \mathrm{t}-$ & 11 & 3 & $\mathbf{5}$ & $\mathbf{6}$ & $\mathbf{6}$ & 4 & 1 & 1 & 1 & 4 & 8 & 8 & 15 \\
\hline $\mathrm{NAO}-/(\Delta \mathrm{t}+)$ & 5 & 3 & 1 & $\mathbf{4}$ & $\mathbf{6}$ & $\mathbf{6}$ & 3 & 3 & 2 & 3 & 13 & 9 & 9 \\
\hline
\end{tabular}

Objaśnienia: jak w tab. 2. Pominięto po 2 miesiące kategorii $\mathrm{NAO}+/(\Delta \mathrm{t}-)$ i $(\mathrm{NAO}-) / \Delta \mathrm{t}+$, a jedyny miesiąc kategorii $\mathrm{NAO}+/ \Delta \mathrm{t}-$ wliczono do kategorii $(\mathrm{NAO}+) / \Delta \mathrm{t}-$

Explanations: as in Table 2. Two months of the categories $\mathrm{NAO}+/(\Delta \mathrm{t}-)$ and $(\mathrm{NAO}-) / \Delta \mathrm{t}+$ were excluded and the sole $\mathrm{NAO}+/ \Delta \mathrm{t}-$ month was included in the category $(\mathrm{NAO}+) / \Delta \mathrm{t}-$

W miesiącach o dużym NAO+ i zarazem $\Delta \mathrm{t}+(21$ miesięcy) średnio dni z cyrkulacją z wycinka SW-NW było 24, a z wycinka NE-SE zaledwie 2; bardzo rzadko pojawiały się też sytuacje bezadwekcyjne. Udział typów cyklonalnych, zerowych i antycyklonalnych był dość wyrównany, z lekką przewagą tych ostatnich (tab. 3). W tej kategorii miesięcy wyróżniło się kilka spośród nich. W lutym 1990 (28 dni) wystąpiła druga pod względem wartości NAO+ $(5,11)$ i jedna z dwóch największych $\Delta \mathrm{t}+$ $\left(6,5^{\circ} \mathrm{C}\right.$, co odpowiada 1,8 odchylenia standardowego $)$; cyrkulacja SW-NW wystąpiła w 24 dniach. Największe odchylenie temperatury powietrza, uznane za anomalne, czyli przekraczające 2 odchylenia standardowe $\left(\Delta t \geq t_{\text {sr. }}+2 \sigma\right)$ objęło wtedy rozległe obszary Europy od Skandynawii i północno-zachodniej Rosji, przez południowo-zachodnią Europę do wysp zachodniej części Morza Śródziemnego (ryc. 2). W Kajaani i Archangielsku anomalia temperatury wyniosła $\Delta \mathrm{t}=10,5^{\circ} \mathrm{C}$, a nawet w Bordeaux przekroczyła $5^{\circ} \mathrm{C}$. W tej samej grupie miesięcy znalazł się również miesiąc poprzedni styczeń $1990\left(\mathrm{NAO}=3,5, \Delta \mathrm{t}=4,5^{\circ} \mathrm{C}\right)$. Wystąpienie dwóch kolejnych tak ciepłych miesięcy (a także dość ciepłego grudnia) sprawiło, że zima 1989/90 była w Europie jedną z najłagodniejszych od połowy XX w. (Kossowska-Cezak, Twardosz 2017). W styczniu 1983 wystąpiła największa styczniowa zarówno $\mathrm{NAO}+(4,82)$, jak i $\Delta \mathrm{t}+\left(5,8^{\circ} \mathrm{C}\right)$; dni z cyrkulacją SW-NW było 29. W lutym 1995 ( $\left.\mathrm{NAO}=3,13, \Delta \mathrm{t}=5,0^{\circ} \mathrm{C}\right)$ dni z cyrkulacją 
z tego sektora było 27 (spośród 28). W grudniu 2015 wystąpiła największa grudniowa zarówno NAO+ $(4,22)$, jak i $\Delta \mathrm{t}+\left(5,4^{\circ} \mathrm{C}\right)$; dni z cyrkulacją $\mathrm{SW}-\mathrm{NW}$ było 23 , ponadto 3 dni z cyrkulacją z kierunku $\mathrm{S}$.

$\mathrm{W}$ miesiącach o dużym $\mathrm{NAO}+$ nie zawsze występuje duża $\Delta \mathrm{t}+\mathrm{W}$ miesiącach o mniejszym odchyleniu temperatury od średniej wieloletniej (NAO+/( $\Delta \mathrm{t}+)$, miesięcy 16 - tab. 2) średnia liczba dni z cyrkulacją SW-NW wyniosła 19 (tab. 3), z sektora przeciwnego, tzn. NE-SE - 3, nieco większy natomiast był udział dni z cyrkulacją

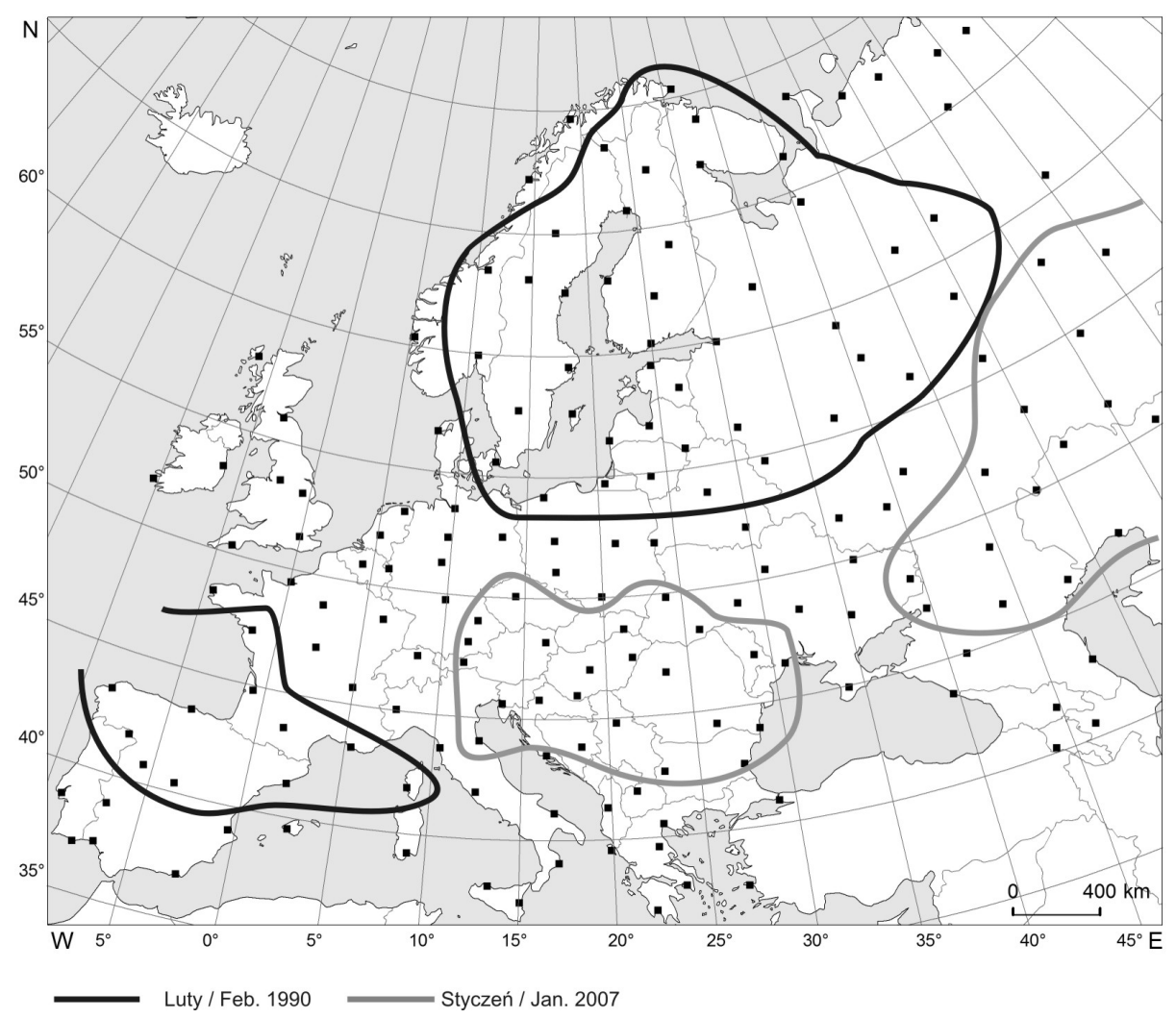

Ryc. 2. Zasięgi dodatniej anomalii termicznej podczas dodatniej fazy NAO: luty 1990 - NAO+/ $\Delta \mathrm{t}+$; styczeń $2007-(\mathrm{NAO}+) / \Delta \mathrm{t}+$

Fig. 2. Ranges of the positive thermal anomaly during the positive NAO phase: February $1990-\mathrm{NAO}+/ \Delta \mathrm{t}+;$ January $2007-(\mathrm{NAO}+) / \Delta \mathrm{t}+\mathrm{E}$

Objaśnienia: jak w tab. 2, zasięgi wyznaczono na podstawie publikacji Kossowska-Cezak, Twardosz 2017).

Explanations: as for Table 2, the ranges are based on the publication by Kossowska-Cezak and Twardosz 2017). 
północną ( $\mathrm{N}-4 \mathrm{dni})$ i/lub południową $(\mathrm{S}-3 \mathrm{dni})$. Na przykład, w styczniu 1974 $\left(\mathrm{NAO}=3,75, \Delta \mathrm{t}=1,4^{\circ} \mathrm{C}\right) \mathrm{z}$ cyrkulacją $\mathrm{N}$ było 2 dni, S 11 dni i SE 5 dni, a w lutym 1961 $\left(\mathrm{NAO}=4,06, \Delta \mathrm{t}=3,3^{\circ} \mathrm{C}\right)$ cyrkulacja $\mathrm{SW}-\mathrm{NW}$ wystąpiła w 14 dniach i N w 6 dniach. W tej kategorii miesięcy znalazł się też luty 1997, z największą 65-leciu wartością $\mathrm{NAO}+=5,26\left(\Delta \mathrm{t}=3,5^{\circ} \mathrm{C}\right)$. Dni z cyrkulacją SW-NW było 23 i 4 dni z wycinka N-E, przez 15 dni występowała cyrkulacja o charakterze antycyklonalnym.

Duże dodatnie odchylenie temperatury od średniej wieloletniej może natomiast wystąpić w miesiącu o względnie niedużej wartości NAO+ $((\mathrm{NAO}+) / \Delta t+;$ miesięcy 19 - tab. 2). W tej grupie miesięcy znalazły się miesiące o zróżnicowanej wartości NAO+ - zarówno bliskie kategorii „duże”, jak i bliskie zeru, dlatego też udział kierunków cyrkulacji w poszczególnych miesiącach był zróżnicowany. Średnio jednak przeważały również dni z cyrkulacją SW-NW - 17 dni (tab. 3), a z cyrkulacją z przeciwnego sektora było średnio 5 dni. Do tej grupy został zaliczony styezeń 2007 , $\mathrm{z}$ jedną z dwóch największych w zimie $\Delta \mathrm{t}=6,5^{\circ} \mathrm{C}$ (1,9 odchylenia standardowego; $\mathrm{NAO}=1,76)$. W tym miesiącu wystąpiło 27 dni z cyrkulacją SW-NW i tylko 1 dzień z cyrkulacją z sektora NE-S; był to zarazem jedyny miesiąc z całkowitym brakiem cyrkulacji antycyklonalnej. Dodatnia anomalia temperatury objęła wtedy środkowo-południową Europę i południowo-wschodnią część Rosji Europejskiej (ryc. 2). Miesiącem kategorii (NAO+)/ $\Delta \mathrm{t}+$ był też luty $1998\left(\mathrm{NAO}=2,44, \Delta \mathrm{t}=5,0^{\circ} \mathrm{C}\right)$, w których było 19 dni z cyrkulacją SW-NW i brakiem dni z cyrkulacją z sektora NE-SE, ale wystąpiło po 3 dni z cyrkulacją $\mathrm{N}$ i S; przeważała cyrkulacja antycyklonalna (15 dni). W tej grupie znalazły się również styczeń 1965 (NAO=0,01, $\Delta \mathrm{t}=3,5^{\circ} \mathrm{C}$ ) i luty $1974\left(\mathrm{NAO}=0,68, \Delta \mathrm{t}=3,9^{\circ} \mathrm{C}\right)$, w którym liczba dni z cyrkulacją SW-NW wyniosła odpowiednio 10 i 12, a NE-SE 11 i 10; w obydwu miesiącach przeważała cyrkulacja cyklonalna, odpowiednio 15 i 13 dni. Warto zwrócić uwagę, że 8 spośród 19 miesięcy tej kategorii wystąpiło w XXI w., co może też świadczyć o zwiększonych zasobach ciepła w wodach Atlantyku (Marsz 2013).

W okresach dodatniej fazy NAO zdarzały się niekiedy miesiące, w których temperatura średnia w Warszawie była niższa od średniej wieloletniej (10 miesięcy w ciągu 65 lat, w tym 5 razy był to marzec, tab. 2). Wśród tych miesięcy był jeden kategorii NAO+/ $\mathrm{t}--$ marzec $1963\left(\mathrm{NAO}=2,79, \Delta \mathrm{t}=-3,7^{\circ} \mathrm{C}\right)$. Przeważała wówczas nad Polską cyrkulacja z sektora NE-SE (14 dni), a z sektora SW-NW było tylko 6 dni. Podczas tego anomalnego miesiąca największe odchylenie temperatury (ponad 2 odchylenia standardowe) wystąpiło w północno-wschodniej Europie (ryc. 3). Luty $2011\left(\mathrm{NAO}=2,79, \Delta \mathrm{t}=-2,0^{\circ} \mathrm{C}\right)$ i marzec $1986\left(\mathrm{NAO}=2,86, \Delta \mathrm{t}=-0,1^{\circ} \mathrm{C}\right)$ weszły w skład kategorii $\mathrm{NAO}+/(\Delta t-)$. W lutym 2011 o niskiej temperaturze zadecydował przeważający udział cyrkulacji SE (11 dni) i przeważnie antycyklonalnej (14 dni). W marcu 1986 temperatura była praktycznie równa średniej wieloletniej, przeważała cyrkulacja z sektora SE-SW (27 dni, w tym SW 15 dni). 


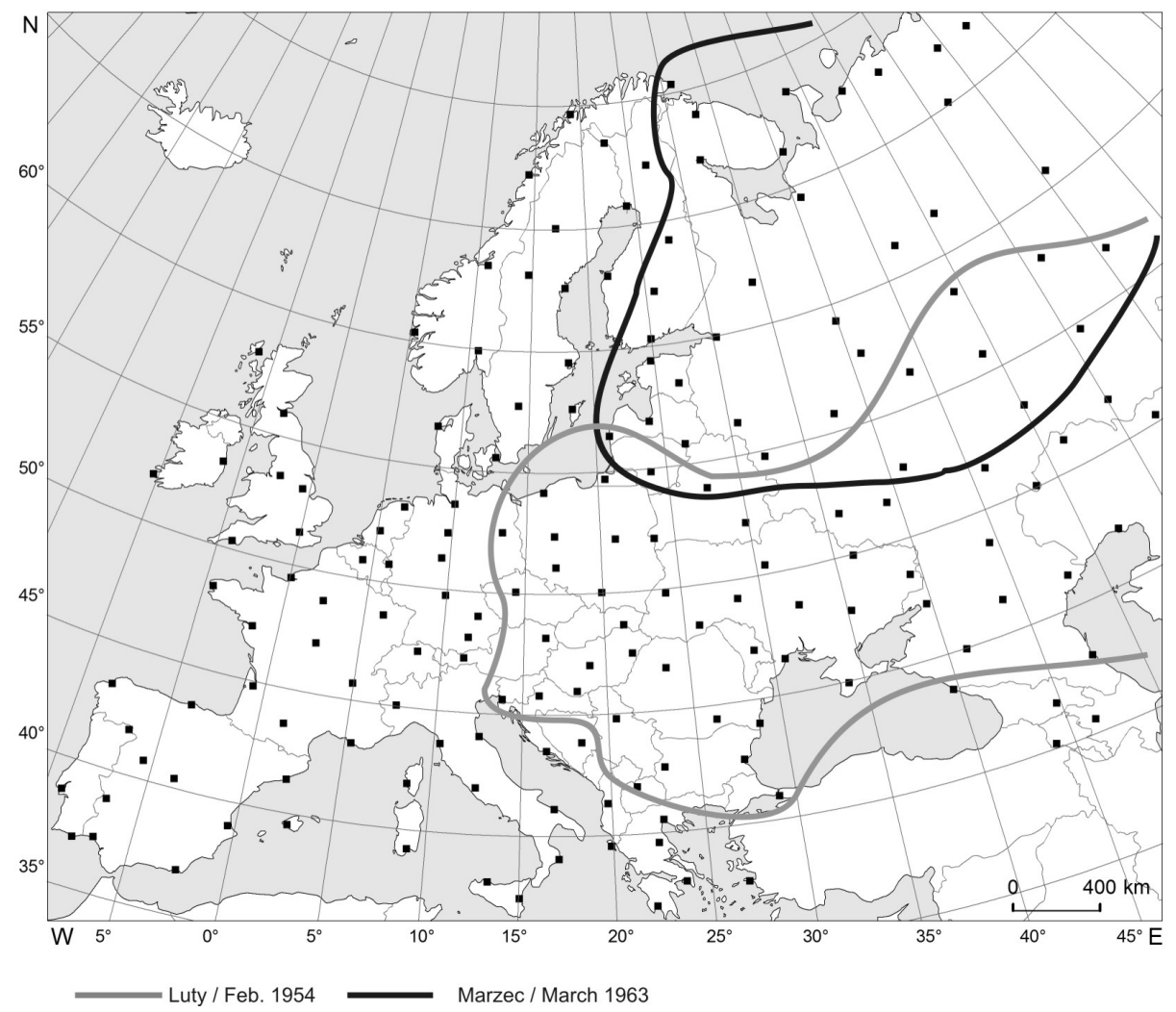

Ryc. 3. Zasięgi ujemnej anomalii termicznej podczas dodatniej fazy NAO: marzec 1963 $\mathrm{NAO}+/ \Delta \mathrm{t}-$; luty $1954-(\mathrm{NAO}+) / \Delta \mathrm{t}-$

Fig. 3. Ranges of the negative thermal anomaly during the positive NAO phase: March $1963-$ $\mathrm{NAO}+/ \Delta \mathrm{t}-;$ February $1954-(\mathrm{NAO}+) / \Delta \mathrm{t}-$

Objaśnienia: jak w tab. 2, zasięgi wyznaczono na podstawie publikacji Kossowska-Cezak, Twardosz 2017). Explanations: as for Table 2, the ranges are based on the publication by Kossowska-Cezak and Twardosz 2017).

Częściej pojawiały się miesiące o większym ujemnym odchyleniu średniej temperatury od średniej wieloletniej, ale niewielkiej wartości dodatniej wskaźnika NAO, tzn. kategorii $(\mathrm{NAO}+) / \Delta \mathrm{t}-(7$ miesięcy). W tych miesiącach wartość NAO osiągała 0,01 - 1,28. Przeważała w nich cyrkulacja z sektora NE-SE (średnio 16 dni - tab. 3), najrzadziej zaś z sektora SW-NW (7 dni); przez połowę miesiąca występowała cyrkulacja antycyklonalna. Wśród miesięcy tej kategorii znalazł się anomalnie zimny luty $1954\left(\mathrm{NAO}=0,57, \Delta \mathrm{t}=-7,8^{\circ} \mathrm{C}\right)$. Anomalia ujemna temperatury objęła wówczas 
znaczne obszary Europy - od południowych krajów nadbałtyckich do wybrzeży Morza Kaspijskiego; w Astrachaniu anomalia temperatury ( $\Delta \mathrm{t}-$ ) wyniosła $-14,0^{\circ} \mathrm{C}$ (ryc. 3 ).

\section{Miesiące o ujemnej wartości wskaźnika NAO}

Podczas ujemnej fazy NAO w miesiącach od grudnia do marca w Warszawie przeważnie występuje temperatura średnia miesięczna poniżej średniej wieloletniej. W tych miesiącach przeważała nad Polską cyrkulacja z wycinka NE-SE, ale jej przewaga nie była tak silna jak cyrkulacji SW-NW w miesiącach z NAO+, częściej natomiast pojawiały się dni z sytuacją bezadwekcyjną.

W miesiącach z dużym NAO- i zarazem dużą $\Delta \mathrm{t}-(22$ miesiące - tab. 2) dni z cyrkulacją z sektora NE-SE było średnio 19, a z sektora przeciwnego tylko 3 (tab. 3 ). Takim miesiącem był grudzień 1996, w którym wystąpiła największa w 65-leciu grudniowa NAO- $\left(-4,70, \Delta \mathrm{t}=-4,7^{\circ} \mathrm{C}\right)$, a także grudzień $2010 \mathrm{z}$ NAO- drugą pod względem wielkości $\left(\mathrm{NAO}=-4,61, \Delta \mathrm{t}=-4,7^{\circ} \mathrm{C}\right)$. Podczas tego ostatniego miesiąca anomalia ujemna temperatury objęła całą północno-zachodnią część Europy (ryc. 4). W tych miesiącach dni z cyrkulacją NE-SE wystąpiło odpowiednio 13 i 15, a z sektora SW-NW tylko 5 i 7; w grudniu 1996 ponadto 6 dni z sytuacją bezadwekcyjną. W styczniu o największym NAO-, w roku 1963 (NAO=-4,09) wystąpiła zarazem największa styczniowa $\Delta \mathrm{t}-$, jednocześnie druga pod względem wielkości ujemna anomalia temperatury w zimie $\left(\Delta \mathrm{t}=-9,8^{\circ} \mathrm{C}\right)$. Miesiąc ten wyróżnił się dominacją cyrkulacji z sektora N-E (27 dni, w tym 13 z NE) i całkowitym brakiem z sektora SW-NW; przeważała cyrkulacja antycyklonalna (21 dni). W tym miesiącu anomalia ujemna temperatury objęła obszar Europy od Wysp Brytyjskich i Francji do zachodniej Rosji i Ukrainy (ryc. 4). Na wschodnich krańcach zasięgu tej anomalii $\Delta \mathrm{t}$ przekroczyła $-10^{\circ} \mathrm{C}$. Tej samej kategorii był kolejny miesiąc - luty 1963 $\left(\mathrm{NAO}=-1,90, \Delta \mathrm{t}=-6,3^{\circ} \mathrm{C}\right)$, z przewagą cyrkulacji NE-SE (25 dni) i również z brakiem cyrkulacji SW-NW. Ujemna anomalia termiczna objęła wówczas zachodnią Europę i wyspy na Morzu Grenlandzkim i Barentsa, gdzie $\Delta$ t przekroczyła $-10^{\circ} \mathrm{C}$ (Kossowska-Cezak, Twardosz 2017). Anomalnie zimna była cała zima 1962/63. Największa ujemna anomalia termiczna w Warszawie w 65 -leciu $\left(\Delta \mathrm{t}=-10,4^{\circ} \mathrm{C}\right)$ wystąpiła również w miesiącu tej kategorii, lutym 1956 (NAO=-2,96). W tym miesiącu dni z cyrkulacją NE-SE było 26, a W i NW razem 2; w 15 dniach była to cyrkulacja antycyklonalna. Luty 1956 był zupełnie wyjątkowy, bo był to jedyny miesiąc w 65-leciu, w którym ujemna anomalia temperatury objęła ponad połowę kontynentu, od Półwyspu Pirenejskiego po Ural (oprócz Skandynawii; ryc. 4). Największa anomalia wystąpiła w środkowej Europie $\left(\Delta \mathrm{t}=-11--12^{\circ} \mathrm{C}\right)$ (Kossowska-Cezak, Twardosz 2017). Warto dodać, że przynajmniej połowa miesięcy tej kategorii została zakwalifikowana jako anomalnie zimne $\left(\Delta \mathrm{t} \leq \mathrm{t}_{\mathrm{sr}}-2 \sigma\right)$. 


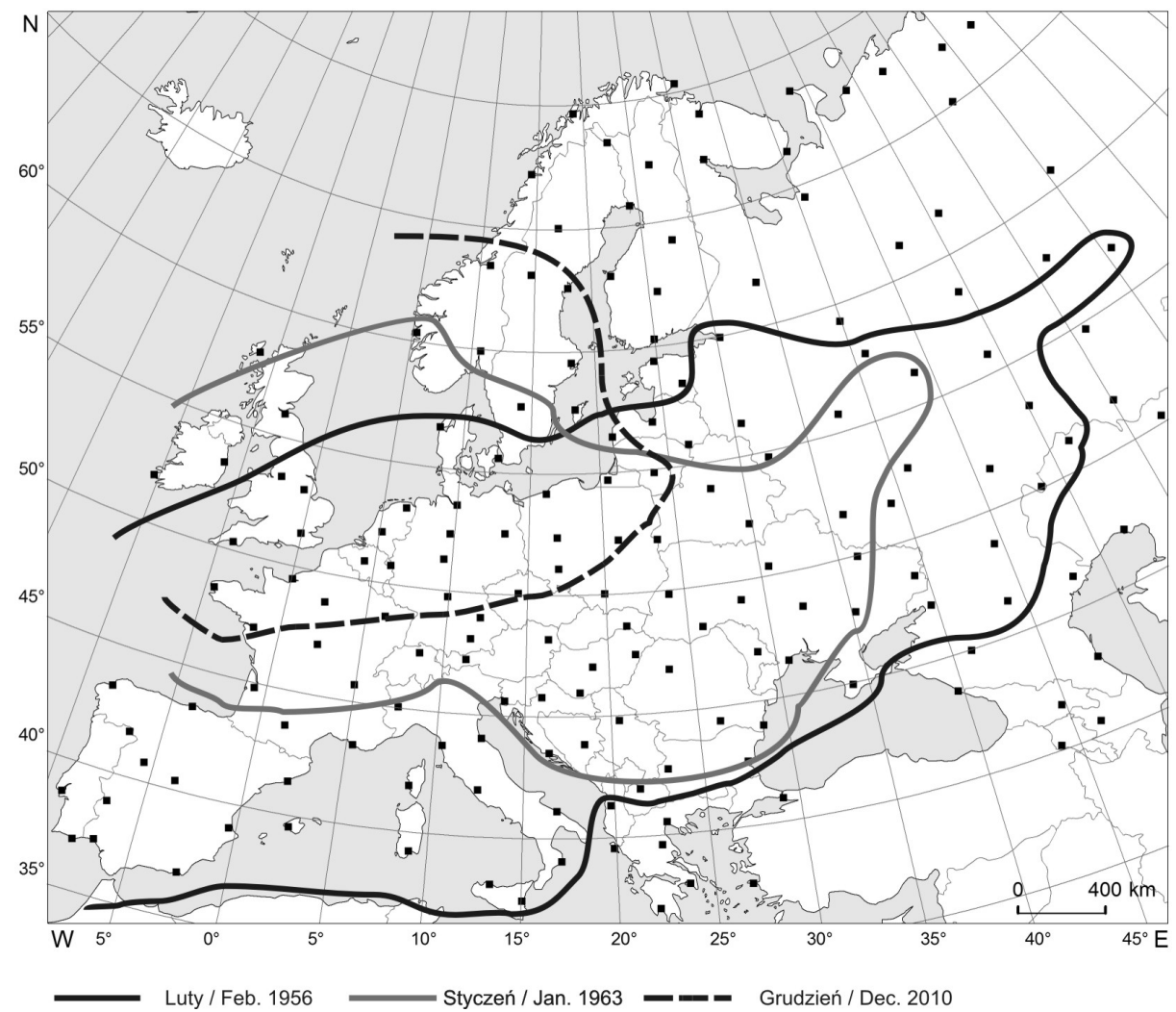

Ryc. 4. Zasięgi ujemnej anomalii termicznej podczas ujemnej fazy NAO - NAO-/At-

Fig. 4. Ranges of the negative thermal anomaly during the negative NAO phase $-\mathrm{NAO}-/ \Delta \mathrm{t}-$ Objaśnienia: jak w tab. 2, zasięgi wyznaczono na podstawie publikacji Kossowska-Cezak, Twardosz 2017). Explanations: as for Table 2, the ranges are based on the publication by Kossowska-Cezak and Twardosz 2017).

Nie we wszystkich miesiącach o dużej NAO- występuje duże odchylenie ujemne temperatury od średniej wieloletniej. W miesiącach kategorii NAO-/( $\Delta t-)$; 13 dni (tab. 2) dysproporcja między liczbą dni z cyrkulacją NE-SE i SW-NW jest mniejsza; średnio odpowiednio 15 i 6 dni (tab. 3). Takim miesiącem był m.in. luty $1969\left(\mathrm{NAO}=-3,16, \Delta \mathrm{t}=-2,6^{\circ} \mathrm{C}\right)$, w którym było 23 dni z cyrkulacją $\mathrm{E}-\mathrm{S}$, w tym 18 z SE, i tylko 2 dni z SW i W razem, a także grudzień $1976\left(\mathrm{NAO}=-3,63, \Delta \mathrm{t}=-0,5^{\circ} \mathrm{C}\right)$, w którym było tylko 12 dni z cyrkulacją NE-SE i 12 z wycinka S-SW.

Znaczne odchylenie temperatury średniej miesięcznej od wieloletniej może natomiast wystąpić w miesiącach o niedużej wartości NAO- (kategoria (NAO-)/ $\Delta \mathrm{t}-$; 


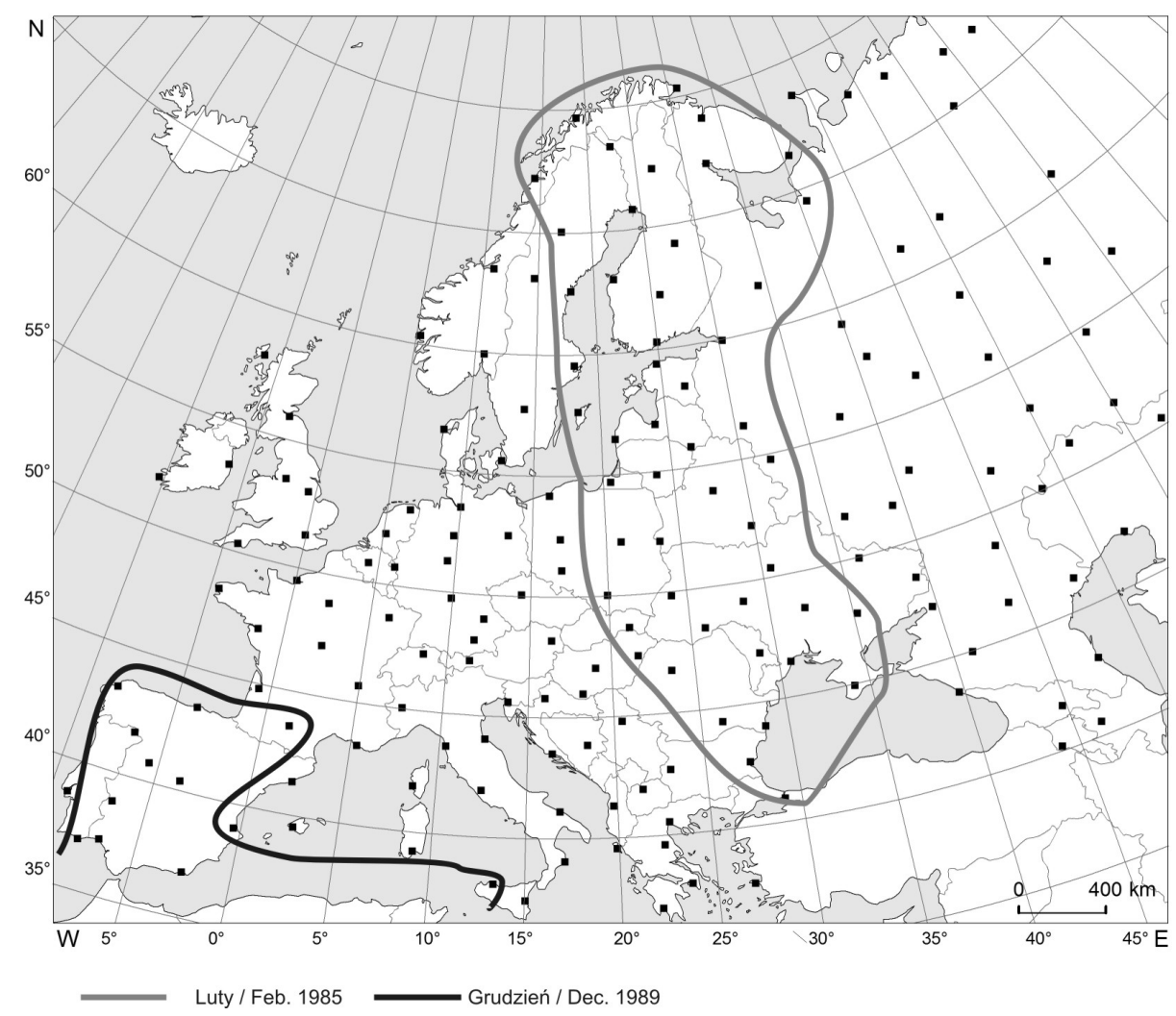

Ryc. 5. Zasięgi dodatniej i ujemnej anomalii termicznej podczas ujemnej fazy NAO: grudzień 1989 - NAO-/At+; luty $1985-(\mathrm{NAO}-) / \Delta \mathrm{t}-$

Fig. 5. Ranges of the positive and negative thermal anomalies during the negative NAO phase: December 1989 - NAO-/At+; February 1985 - (NAO-) / $\Delta \mathrm{t}-$

Objaśnienia: jak w tab. 2, zasięgi wyznaczono na podstawie publikacji Kossowska-Cezak, Twardosz 2017). Explanations: as for Table 2, the ranges are based on the publication by Kossowska-Cezak and Twardosz 2017).

11 miesięcy - tab. 2). W tych miesiącach wystąpiło średnio 17 dni z cyrkulacją NE-SE i 3 dni z SW-NW; względnie częsta była sytuacja bezadwekcyjna i typy cyrkulacji antycyklonalne (tab. 3). Do tej kategorii zaliczają się m.in.: styczeń 1972 (NAO=-0,52, $\left.\Delta \mathrm{t}=-4,8^{\circ} \mathrm{C}\right)$, styczeń $2006\left(\mathrm{NAO}=-0,10, \Delta \mathrm{t}=-4,8^{\circ} \mathrm{C}\right)$, luty $1985(\mathrm{NAO}=-0,24$, $\left.\Delta \mathrm{t}=-7,4^{\circ} \mathrm{C}\right)$ czy marzec $1964\left(\mathrm{NAO}=-0,77, \Delta \mathrm{t}=-4,9^{\circ} \mathrm{C}\right)$. We wszystkich tych miesiącach przeważały dni z cyrkulacją z sektora E-S albo NE-SE (przynajmniej 20 dni) i z bardzo nielicznymi dniami lub całkowitym brakiem dni z cyrkulacją SW-NW 
(styczeń 1972, marzec 1964). Na uwagę zasługuje charakterystyczny rozległy obszar występowania ujemnej anomalii temperatury $\left(\Delta \mathrm{t} \leq \mathrm{t}_{\text {sr. }}-2 \sigma\right)$ w lutym 1985 od Skandynawii po Bałkany i Morze Czarne (ryc. 5).

W okresach z ujemną fazą NAO zdarzają się też pojedyncze miesiące z temperaturą średnią powyżej średniej wieloletniej (razem 7), ale w żadnym z tych miesięcy obydwie charakterystyki nie osiągnęły kategorii „duża”. W 5 miesiącach wystąpiła duża NAO-, której towarzyszyła nieznaczna $\Delta \mathrm{t}+\left(0,2-1,9^{\circ} \mathrm{C}\right)$. W tych miesiącach zaznaczyła się niewielka przewaga liczby dni z cyrkulacją NE-SE (11 dni) nad SW-NW (8 dni), ale przy znacznym udziale dni z cyrkulacją S (6 dni, tab. 3). O tej grupie miesięcy należy więc raczej mówić, że odznaczyły się one przewagą cyrkulacji z sektora południowego (SE-SW - średnio 15 dni) w stosunku do północnego (NW-NE - 6 dni - tab. 2), choć w poszczególnych miesiącach cyrkulacja atmosferyczna nad Polską kształtowała się różnie. Na przykład, w styczniu 1977 (NAO=-2,36, $\left.\Delta \mathrm{t}=0,7^{\circ} \mathrm{C}\right)$ cyrkulacja z sektora SE-SW występowała przez 25 dni (w tym S 14 dni), a z NW-NE tylko $3 \mathrm{dni}$, natomiast w grudniu $1989\left(\mathrm{NAO}=-2,23, \Delta \mathrm{t}=1,8^{\circ} \mathrm{C}\right)$ odpowiednio 11 i 10 dni. Zwarty obszar z anomalią dodatnią temperatury w tym ostatnim miesiącu zaznaczył się w południowo-zachodniej Europie (ryc. 5). W dwóch miesiącach (marzec 1974 i 1999) o niewielkim NAO- (poniżej -1) wystąpiła względnie duża $\Delta \mathrm{t}+\left(\right.$ jednakowo $\left.2,6^{\circ} \mathrm{C}\right)$. Oba te miesiące wyróżniły się dużą liczbą dni z cyrkulacją SE (14 i 11 dni), przy ogólnie dużym udziale cyrkulacji z sektora E-S (24 i 19 dni) i bardzo małym z sektora NW-NE (1-3 dni).

\section{Podsumowanie i wnioski}

Poszukiwanie związku miesięcznych warunków termicznych w Warszawie z wielkością miesięcznej wartości wskaźnika NAO w miesiącach zimowych lat 1951-2015 doprowadziło do kilku spostrzeżeń.

Przy znacznej wartości dodatniej wskaźnika NAO (przynajmniej 2,5; w marcu 2), wskazującej na silny spływ zachodni, nad środkową Europą przeważa cyrkulacja z sektora zachodniego (SW-NW), przy znikomym udziale lub całkowitym braku cyrkulacji z sektora przeciwnego. Adwekcja morskich mas powietrznych zimą sprawia, że nad Polską utrzymuje się temperatura o kilka stopni (nawet $5-6^{\circ} \mathrm{C}$ i więcej) wyższa od średniej wieloletniej. Na ogół im większa liczba dni z cyrkulacją zachodnią, tym wyższa temperatura.

Równie duże odchylenie dodatnie temperatury może też wystąpić przy niewielkiej wartości wskaźnika NAO+, jeżeli przewaga cyrkulacji zachodniej nad Polską jest podobna jak w miesiącach o dużym NAO+ (np. styczeń 2007). Można stąd wysnuć wniosek, że wielkość wskaźnika NAO, obliczana na podstawie wartości ciśnienia atmosferycznego w ustalonych punktach (co jest niezbędne dla celów 
porównawczych), nie zawsze oddaje rzeczywiste nasilenie zachodniego przenosu mas powietrznych, sterowanego przez rzeczywistą różnicę ciśnienia między centrami Wyżu Azorskiego i Niżu Islandzkiego.

Jeżeli nad Europą tworzą się regionalne układy ciśnienia, które modyfikują kierunek adwekcji mas powietrznych docierających do środkowej Europy, mimo dodatniej fazy NAO, może nad Polską przeważać cyrkulacja kierunków wschodnich i w konsekwencji temperatura poniżej średniej wieloletniej (np. marzec 1963, luty 1954). Okazuje się bowiem, że temperatura średnia miesięczna wyraźnie wyższa lub niższa od średniej wieloletniej lepiej nawiązuje do kierunków adwekcji nad Polską niż do natężenia przenosu zachodniego wyrażonego wielkością wskaźnika NAO, aczkolwiek cechy termiczne mas powietrznych nie są w pełni zdeterminowane przez kierunek ich napływu.

W miesiącach w ujemnej fazie NAO cyrkulacja jest bardziej zróżnicowana niż w fazie dodatniej, czego można było się spodziewać. Cyrkulacja z sektora zachodniego nad Polską pojawia się rzadko (w pojedynczych dniach) albo nie występuje w ogóle, natomiast przewagę zyskuje cyrkulacja z sektora wschodniego, ale zwykle ta przewaga nie jest tak silna jak w fazie dodatniej cyrkulacja z sektora zachodniego. Przypadki silnego skupienia kierunków adwekcji tylko do jednego sektora w ciągu całego miesiąca zdarzają się rzadko i to tylko w lutym (np. w lutym 1929, najzimniejszym w XX w. w Warszawie, cyrkulacja z sektora NE-SE wystąpiła w 24 dniach, wskaźnik NAO bliski zeru).

Adwekcja powietrza ze wschodu i/albo północy w tych miesiącach sprawiła, że w środkowej Europie wystąpiła wówczas ujemna anomalia temperatury (Kossowska-Cezak, Twardosz 2017). W miesiącach o mniejszej przewadze cyrkulacji z wycinka N-E-SE odchylenie temperatury poniżej średniej wieloletniej zwykle bywa mniejsze, natomiast w miesiącach, w których wskaźnik NAO- jest mniejszy, przewaga cyrkulacji N-E-SE może być duża i w wyniku temperatura powietrza znacznie poniżej średniej wieloletniej (np. styczeń 1972: $\mathrm{NAO}=-0,52, \Delta \mathrm{t}=-4,8^{\circ} \mathrm{C}$; $\mathrm{SE}-15 \mathrm{dni}, \mathrm{S}-10$ dni, cyrkulacja antycyklonalna $20 \mathrm{dni}$ ).

Należy tu zwrócić uwagę, że w miesiącach w ujemnej fazie NAO wyróżniających się szczególnie niską temperaturą na ogół duży udział ma cyrkulacja w zasięgu wyżu, co pośrednio wskazuje na rolę wielkości zachmurzenia w kształtowaniu warunków termicznych w okresie zimy (nocne wychłodzenie drogą wypromieniowania podczas długiej bezchmurnej nocy).

W ujemnej fazie NAO możliwe jest wystąpienie w Polsce temperatury powyżej średniej wieloletniej. Dochodzi do tego wówczas, gdy następuje wzmożona cyrkulacja z sektora południowego, odchylenie temperatury jednak nie osiąga takich wartości jak w ciepłych miesiącach w dodatniej fazie NAO, z adwekcją z zachodu.

Przeprowadzona analiza potwierdziła dotychczas znane prawidłowości dotyczące wpływu wyraźnie zaznaczonej dodatniej lub ujemnej fazy NAO na warunki termiczne 
w Polsce w okresie zimy. Wykazała również, że zdarzają się jednak odstępstwa od tych prawidłowości, które należy przypisywać regionalnym układom barycznym nad Europą, które sterują adwekcją nad obszarem Polski i które bezpośrednio wpływają na warunki termiczne tutaj występujące. Jednocześnie trzeba mieć na uwadze, że kierunek adwekcji nie określa jednoznacznie cech termicznych napływającej masy powietrznej.

\section{Podziękowania}

Autorzy serdecznie dziękują Pani Krystynie Pianko-Kluczyńskiej za udostępnienie kalendarza typów cyrkulacji.

\section{Literatura}

Glossary of Meteorology, 2000, T.S. Glickmann (red.), American Meteorological Society, Boston. International Meteorological Vocabulary, 1992, World Meteorological Organization, Geneva.

Hurrell J.M., 1995, Decadal trends in North Atlantic Oscillation and relationship to regional temperature and precipitation, Science, 269, 676-679.

Hurrell J.W., Van Loon H., 1997, Decadal variations in climate associated with the North Atlantic Oscillation, Climatic Change, 36, 301-326.

Jones P.D., Jonsson T., Wheeler D., 1997, Extension to the North Atlantic Oscillation using early instrumental pressure observations from Gibraltar and South-West Iceland, International Journal of Climatology, 17, 1433-1450.

Kaszewski B.M., 1992, Typy cyrkulacji a typy pogody w Polsce, Rozprawy habilitacyjne, 42, Wydawnictwo UMCS, Lublin.

Kirschenstein M., Baranowski D., 2009, Wahania rocะne i tendencje smian temperatury powietræa w Koszalinie, Słupskie Prace Geograficzne 6, 167-178.

Kossowska-Cezak U., Twardosz R., 2017, Anomalie termiczne w Europie (1951-2010), Instytut Geografii i Gospodarki Przestrzennej, Uniwersytet Jagielloński, Kraków.

Lityński J., 1969, Lic»bowa klasyfikacja typów cyrkulacji i typów pogody dla Polski, Prace PIHM, 97, 3-15.

Marsz A.A., 2002, Wprowadzenie (istota NAO, historia, wska:niki), [w:] A.A. Marsz, A. Styszyńska (red.), Oscylacja Pótnocnego Atlantyku i jej rola w kształtowaniu zmienności warunków klimatycznych i hydrologicznych Polski a temperatura powietræa nad Polskq, Akademia Morska, Gdynia, 11-29.

Marsz A.A., 2013, Wptyw Oscylacji Pótnocnoatlantyckiej (NAO) na wærost temperatury powietræa nad Polskq w warunkach smiennych sasobów ciepta w Atlantyku Pótnocnym, Przegląd Geofizyczny, 3-4, 127-143.

Merecki R.,1914, Klimatologia ziem polskich, Drukarnia i Litografia Jana Cotty. 
Niedźwiedź T., 2002, Relacje między NAO a wskaźnikami cyrkulacji nad Polskq, [w:] A.A. Marsz, A. Styszyńska (red.), Oscylacja Pótnocnego Atlantyku i jej rola w ksztattowaniu zmienności warunków klimatycznych i hydrologicznych Polski a temperatura powietræa nad Polskq, Akademia Morska, Gdynia, 87-97.

Nowosad M., 2005, Jeszcze o historii badań nad Oscylacja Pótnocnego Atlantyku, Wiadomości Instytutu Meteorologii i Gospodarki Wodnej, 18 (1), 81-88.

Pianko-Kluczyńska K., 2007, Nowy kalendarz typów cyrkulacji atmosfery wedtug J. Lityńskiego, Wiadomości Meteorologii, Hydrologii, Gospodarki Wodnej, I(LI) (4), 65-85.

Rogers J.C., 1984, The association between the North Atlantic Oscillation and the Southern Oscillation in the Northern Hemisphere, Monthly Weather Review, 112, 1999-2015.

Stownik meteorologiczny, 2003, T. Niedźwiedź (red.), PTGeof. / IMGW, Warszawa.

Styszyńska A., 2002, Wskaæniki NAO a typy cyrkulacji atmosferycznej Osuchowskiej-Klein, [w:] A.A. Marsz, A. Styszyńska (red.). Oscylacja Pótnocnego Atlantyku i jej rola w kształtowaniu zmienności warunków klimatycznych i hydrologicznych Polski a temperatura powietræa nad Polskq, Akademia Morska, Gdynia, 99-109.

Świątek M., 2014, Uwarunkowania cyrkulacyjne występowania cieptych miesięcy zimowych na obszarze Pobreezy Potudniowobattyckich, Prace Geograficzne, 139, 43-56.

Wibig J., 2000, Oscylacja Pótnocnoatlantycka i jej wptyw na ksztattowanie pogody i klimatu, Przegląd Geofizyczny, 2, 121-137.

Wibig J., 2001, Wptyw cyrkulacji atmosferycznej na rozktad przestrzenny anomalii temperatury i opadów w Europie, Wydawnictwo Uniwersytetu Łódzkiego.

Ustrnul Z., Czekierda D., 2007, Wptyw wskaźnika Oscylacji Pótnocnoatlantyckiej na średniq temperature powietrza w różnych skalach przestrzennych, [w:] K. Piotrowicz, R. Twardosz (red.), Wahania klimatu w różnch skalach præestrzennych i cæasowych, Instytut Geografii i Gospodarki Przestrzennej, Uniwersytet Jagielloński, Kraków, 2007, 75-84.

Urszula Kossowska-Cezak

Uniwersytet Warswawski

Wydziat Geografii i Studiów Regionalnych

ul. Krakowskie Przedmieście 30, 00-927 Warszawa

Robert Twardos:

Uniwersytet Jagiellonski w Krakowie

Instytut Geografii i Gospodarki Præestrzennej

ul. Gronostajowa 7, 30-387 Kraków

r.twardosz@uj.edu.pl 
